\title{
Psychological Impact and Coping Strategies of Dental Students during the COVID-19 Pandemic: A Cross-Sectional Survey
}

\author{
Trudee Hoyte ${ }^{1}$, Anne Kowlessar ${ }^{1}$, Kevin Henry ${ }^{2}$, Adilah Mahbir ${ }^{1}$, Anil Ali ${ }^{1}$, Tichard Manwah ${ }^{1}$ \\ ${ }^{1}$ School of Dentistry, Department of Child Dental Health, The University of the West Indies, St. Augustine, Trinidad \\ ${ }^{2}$ School of Dentistry, Department of Oral Diseases, The University of the West Indies, St. Augustine, Trinidad \\ Email: trudee.hoyte@sta.uwi.edu
}

How to cite this paper: Hoyte, T., Kowlessar, A., Henry, K., Mahbir, A., Ali, A., \& Manwah, T. (2021). Psychological Impact and Coping Strategies of Dental Students during the COVID-19 Pandemic: A CrossSectional Survey. Creative Education, 12, 1926-1938.

https://doi.org/10.4236/ce.2021.128147

Received: July 27, 2021

Accepted: August 16, 2021

Published: August 19, 2021

Copyright $\odot 2021$ by author(s) and Scientific Research Publishing Inc. This work is licensed under the Creative Commons Attribution International License (CC BY 4.0).

http://creativecommons.org/licenses/by/4.0/

(c) (i) Open Access

\begin{abstract}
Background: The COVID-19 pandemic has affected the delivery of the curriculum of dental schools. The psychological impact and coping strategies of dental students in Trinidad and Tobago are a matter of concern. In this study, dental students were asked to evaluate their mental health and coping strategies regarding COVID-19. Methods: A survey was conducted using an online platform. Demographic data was collected and the psychological impact was assessed. Participants were also questioned on their coping strategies. Descriptive statistics, Chi-square test, Mann-Whitney test and a logistic regression were performed. Results: A total of 108 out of 137 students participated. Their mean age was 22.96 years. High levels of stress (59.26\%), anxiety (64.81\%) and depression $(76.85 \%)$ were observed among dental students. Nationality and gender played a significant role in the students' mental health scores. Female students were more likely to experience stress, anxiety and depression than males $(\exp [\beta]=-0.38,-0.21$, and -2.31$)$. There were various coping mechanisms deployed by dental students. Conclusion: The elevated levels of stress, anxiety and depression in these dental students emphasize the need for psychological intervention.
\end{abstract}

\section{Keywords}

Depression, Anxiety, Stress, Dental Students, DASS-21 Scale, Trinidad and Tobago, COVID-19 Pandemic

\section{Introduction}

A pandemic is defined as the spread of a particular disease across international borders or worldwide, affecting a large number of people (Kelly, 2011). In December 
2019, in Wuhan, China, an outbreak of pneumonia with an unknown aetiology was reported (Ge, Yang, Xia, Fu, \& Zhang, 2020). A new coronavirus, SARS-CoV-2, was identified as the causative agent of the severe acute respiratory syndrome (Meng, Hua, \& Bian, 2020; Phelan, Katz, \& Gostin, 2020). The virus spread very rapidly around the world. It was the seventh coronavirus to infect humans. As it was discovered in 2019, it became known as coronavirus disease 2019 (COVID-19) (Ge et al., 2020; Phelan et al., 2020). On March 12, 2020, the COVID-19 virus status was raised to a pandemic (World Health Organization, 2020).

There were severe restrictions on the practice of dentistry worldwide. Like in most countries, dentists in Trinidad and Tobago were initially only allowed to perform emergency treatment. All educational institutions were initially closed and switched to online teaching. Hence, face-to-face teaching of dentistry in Trinidad and Tobago was disrupted.

The dental school in Trinidad and Tobago is the only one, this school started in 1989 (Hoyte, Henry, Kowlessar, Ali, \& Mahabir, 2021). The school at that time encountered several problems in relation to its digital platform. Some students reported not having digital devices or stable internet connections. The university encouraged international students to return home. Dental treatment by students on patients at the dental school was stopped and examinations were rescheduled. Didactic teaching and examinations were reformatted to be administered online.

\section{Literature Review}

Stress is experienced in reaction to a threat to psychological, intellectual or somatic wellbeing (Holland, 2016). Anxiety can be defined as a feeling expressed by stressed considerations, strain and physical changes (Bashir et al., 2020). Depression can be defined as a mental disorder characterized by low self -esteem, feelings of blame, loss of intrigue, sleep disturbance, hunger, sluggishness and poor concentration (Bashir et al., 2020).

Stressors to dental students can be categorized into educational environment, academics, clinical factors, personal and living accommodation (Alzahem, Van der Molen, Alaujan, \& De Boer, 2014). One study reported the prevalence of stress among dental students to be 100\% (Ahmad, Md Yusoff, \& Abdul Razak, 2011).

Stress is an aetiological factor for physical and mental illness (Henry \& Crawford, 2005; Wang et al., 2020). The lockdown and restrictions implemented caused anxiety and affected the mental health of the population including dental students (Iyer, Aziz, \& Ojcius, 2020; Zhai \& Du, 2020). Cao et al. (Cao et al., 2020) reported higher levels of anxiety correlated to factors such as having a COVID-19 positive patient among medical college students. During lockdown all learning platforms were virtual and because everyone is required to stay at home this increased anxiety among dental students. The abrupt shift to virtual teaching, the possible death by COVID-19, lockdowns and separation has raised the levels of anxiety (Fangyuan et al., 2020). Chakraborty et al. reported higher levels of depression among dental students during the COVID-19 pandemic. 
These students attributed their increase in depression to worry about professional growth due to the disruption and thereby reduction in their clinical training. Disruption in research experience and employment prospects also contributed to their depression (Chakraborty, Subbiah, \& Damade, 2020).

Studies have reported that dental education can be a major cause of stress, and higher levels of stress were seen in dental students when compared to the general population (Cooper, Watts, \& Kelly, 1987). This was attributed to clinical training requirements, workload, and examinations leading to higher levels of stress, anxiety and depression (Basudan, Binanzan, \& Alhassan, 2017). Poor examination grades have been shown to contribute to academic pressure, social isolation, decreased self-care practices and self-esteem (Adams, 2017; Laurence, Williams, \& Eiland, 2009). Prolonged implementations of restrictions to the practice of dentistry and lockdowns could affect students' academic performance and have a debilitating effect on their mental health. Dental students in particular may face hurdles with different aspects of their education such as examinations and clinical requirements, which would add to their stress. Al-Sowygh et al. showed that course clinical requirements and performance pressures are dental students greatest stressors (Al-Sowygh, Alfadley, Al-Saif, \& Al-Wadei, 2013).

The environment of a dental school is rigorous, competitive, and demanding (Burk \& Bender, 2005; Divaris et al., 2008; Polychronopoulou \& Divaris, 2005). The suspension of direct patient care is the biggest challenge to dental students as this is an important part of their curriculum (CODA, 2016). It was unclear of the impact on the students' mental health. The mental health and well-being of students is of utmost importance, and the need for professional intervention should be assessed (Iyer et al., 2020; Zhai \& Du, 2020).

Dental schools have offered stress management courses, relaxation techniques, and counselling to assist students with coping (Klaassen et al., 2021). Sreeram and Mundada reported that living with parents was one way dental students reported coping with the pandemic (Sreeram \& Mundada, 2021).

The impact of COVID-19 on mental health has been acknowledged as a high research priority (Holmes et al., 2020). Measurement of stress, anxiety and depression can be done using the Depression, Anxiety and Stress scale (DASS-21) (Lovibond, Lovibond, \& Psychology Foundation of Australia, 1995). In this study, dental students were asked to evaluate their mental health and coping strategies regarding COVID-19.

\section{Materials and Methods}

\subsection{Ethical Approval}

Ethical approval was received from The University of The West Indies ethics committee, and the registrar's office (CREC-SA.0593/11/32020), and informed consent was obtained from participants.

\subsection{Research Design}

A cross-sectional survey using a self-administered questionnaire was developed. 
A pilot study was conducted using 38 students in the final year that were delayed in the system due to COVID-19. After the first COVID-19 case was reported in Trinidad and Tobago on 12 March 2020 (Charan, 2020) their education including final exam date was delayed since all schools were closed by the government. Results from the pilot were used to identify any problems, and modifications were made to the questionnaire. These students were excluded from the final analysis. The survey was administered to all current students via the dental students association email listing.

\subsection{Data Collection}

The data was anonymously collected online via survey planet (Survey Planet LLC, Marini Del Ray, CA, USA) on February $4^{\text {th }} 2021$, followed by reminders on the $18^{\text {th }}$ February and $4^{\text {th }}$ March. The questionnaire was available for five weeks, and the window period for responses closed on March $11^{\text {th }} 2020$. The front page of the survey informed the students that their participation was anonymous and voluntary. If any students felt stressed while filling out the survey a number for the university's medical and counselling unit was also provided. Their informed consent was then obtained.

The self-administered questionnaire had two parts. The first part asked for demographic data (gender, age, nationality, year of study, living situation, financial assistance and funding for study). The second part of the survey assessed both their psychological health (using the DASS-21 scale) and coping mechanisms. The validity and reliability of the DASS-21 scale have been previously reported (Lovibond et al., 1995). Psychological health was divided into stress, depression, and anxiety. The DASS-21 scale was composed of 3 parts each contained 7 items. To assess the perception levels a 4-point scale was used. The scores for stress, anxiety and depression were calculated by summing the scores of the specific items. This was then interpreted as normal, mild, moderate, severe and extremely severe. The range for each scale was 0 to 28 . The entire questionnaire had scores that ranged from 0 to 84 .

\subsection{Statistical Analysis}

The data was analyzed using the SPSS version 27 (IBM SPSS Statistics for Windows version (IBM Corp., Armonk N.Y., USA)). From the questionnaire responses, demographic data and descriptive statistics were tabulated. Proportion comparisons were calculated as well as a logistic regression analyses to assess the association between demographic and psychologic data. The reliability of the questionnaire was assessed using Cronbach's alpha.

\section{Results}

\subsection{Demographic Data of the Participants}

The total number of students enrolled at the dental school was 137. One hundred and eight (108) completed the survey giving a good response rate of 
$78.83 \%$.

Age data from two participants were not filled out. The mean age was 22.96 years with a $95 \%$ confidence interval of $(22.37,23.56)$ and $76.9 \%$ of respondents were females. The majority (86.1\%) of the participants were Trinidadian nationals of which $82.4 \%$ lived with their family. Only $2(1.9 \%)$ lived with their spouse/children. The majority of students (68.6\%) got financial assistance and this was mainly from the Government Assistance for Tuition Expenses Programme (G.A.T.E) (25\%). These results are summarized in Table 1.

Table 1. Demographics of sample.

\begin{tabular}{|c|c|c|c|}
\hline Variable & & $\%$ & $\mathrm{~N}=108$ \\
\hline \multirow[t]{3}{*}{ Gender } & Female & 76.9 & 83 \\
\hline & Male & 21.3 & 23 \\
\hline & Prefer not to say & 1.9 & 2 \\
\hline \multirow[t]{5}{*}{ Year of Study } & $1^{\text {st }}$ year $(2021)$ & 15.7 & 17 \\
\hline & $2^{\text {nd }}$ year $(2022)$ & 25.9 & 28 \\
\hline & $3^{\text {rd }}$ year $(2023)$ & 17.6 & 19 \\
\hline & $4^{\text {th }}$ year $(2024)$ & 23.1 & 25 \\
\hline & $5^{\text {th }}$ year $(2025)$ & 17.6 & 19 \\
\hline \multirow[t]{9}{*}{ Nationality } & Bahamian & 0.9 & 1 \\
\hline & Barbadian & 4.6 & 5 \\
\hline & British & 0.9 & 1 \\
\hline & Grenadian & 0.9 & 1 \\
\hline & Jamaican & 1.9 & 2 \\
\hline & Nigerian & 0.9 & 1 \\
\hline & Trinidadian & 86.1 & 93 \\
\hline & Vincentian & 2.8 & 3 \\
\hline & Missing & 0.9 & 1 \\
\hline \multirow[t]{5}{*}{ Living situation } & Dormitory & 5.6 & 6 \\
\hline & Live alone & 7.4 & 8 \\
\hline & With Family & 82.4 & 89 \\
\hline & With spouse/children & 1.9 & 2 \\
\hline & Other & 2.8 & 3 \\
\hline \multirow[t]{2}{*}{ Financial Assistance } & No & 31.5 & 34 \\
\hline & Yes & 68.5 & 74 \\
\hline \multirow[t]{4}{*}{ Tuition Funding } & $\begin{array}{c}\text { Government Assistance for Tuition } \\
\text { Expenses Programme (G.A.T.E) }\end{array}$ & 50.9 & 55 \\
\hline & Partial/Full Scholarship & 25 & 27 \\
\hline & Self-Funded & 12 & 13 \\
\hline & Other & 12 & 13 \\
\hline
\end{tabular}




\subsection{Statistical Results}

Table 2 shows percentage of DASS-21 responses. The internal reliability of the DASS-21 questions was excellent $(\alpha=0.9497)$. There were no dental students showing extreme stress levels. Extremely severe anxiety (37.96\%) and depression levels (30.56\%) were found (Table 3).

Based on gender and nationality there were noteworthy differences in the students'scores (Table 4). The Female students were more depressed than male students and it was statistically significant $(p<0.05)$.

Comparing females to males, male students were less likely to experience stress, anxiety and depression, $(\exp [\beta]=-3.12,-1.22$, and -1.74 respectively) Table 5.

Table 2. Percentage of DASS-21 responses of participants.

\begin{tabular}{|c|c|c|c|c|}
\hline & $\begin{array}{c}\text { Never } \\
\%\end{array}$ & $\begin{array}{c}\text { Sometimes } \\
\%\end{array}$ & $\begin{array}{l}\text { Often } \\
\%\end{array}$ & $\begin{array}{l}\text { Almost } \\
\text { Always } \%\end{array}$ \\
\hline \multicolumn{5}{|l|}{ Stress questions } \\
\hline I found it hard to wind down & 14.8 & 32.4 & 33.3 & 19.4 \\
\hline I tended to overreact to situations & 19.4 & 25.0 & 25.0 & 30.6 \\
\hline I felt that I was using a lot of nervous energy & 19.6 & 26.2 & 32.7 & 21.5 \\
\hline I found myself getting agitated/irritable & 14.8 & 24.1 & 39.8 & 21.3 \\
\hline I found it difficult to relax & 15.0 & 26.2 & 32.7 & 26.2 \\
\hline $\begin{array}{l}\text { I was intolerant of anything that kept me from getting } \\
\text { on with what I was doing }\end{array}$ & 24.3 & 43.0 & 17.8 & 15.0 \\
\hline I felt that I was rather touchy/sensitive & 20.8 & 37.7 & 21.7 & 19.8 \\
\hline \multicolumn{5}{|l|}{ Anxiety questions } \\
\hline I was aware of dryness of my mouth & 44.4 & 24.1 & 18.5 & 13.0 \\
\hline I experienced difficulty breathing & 53.7 & 24.1 & 16.7 & 5.6 \\
\hline I experienced tremors/trembling & 52.8 & 28.3 & 8.5 & 10.4 \\
\hline $\begin{array}{l}\text { I was worried about situations in which I might panic } \\
\text { and embarrass myself }\end{array}$ & 26.2 & 19.6 & 26.2 & 28.0 \\
\hline I felt I was close to panic & 24.1 & 34.3 & 24.1 & 17.6 \\
\hline I experienced palpitations & 48.1 & 24.1 & 17.6 & 10.2 \\
\hline I felt scared without reason & 39.8 & 22.2 & 19.4 & 18.5 \\
\hline \multicolumn{5}{|l|}{ Depression questions } \\
\hline I could not seem to experience any positive feeling at all & 25.9 & 44.4 & 23.1 & 6.5 \\
\hline I found it difficult to work up the initiative to do things & 8.4 & 28.0 & 28.0 & 35.5 \\
\hline I felt that I had nothing to look forward to & 24.1 & 33.3 & 17.6 & 25.0 \\
\hline I felt down & 10.2 & 19.4 & 39.8 & 30.6 \\
\hline I was unable to become enthusiastic about anything & 21.7 & 31.1 & 28.3 & 18.9 \\
\hline I felt I was not worth much as a person & 45.8 & 21.5 & 16.8 & 15.9 \\
\hline I felt that life was meaningless & 43.5 & 20.4 & 17.6 & 18.5 \\
\hline
\end{tabular}


Table 3. Levels of stress, anxiety and depression of dental students.

\begin{tabular}{cccc}
\hline Levels & $\begin{array}{c}\text { Stress } \\
(\%)\end{array}$ & $\begin{array}{c}\text { Anxiety } \\
(\%)\end{array}$ & $\begin{array}{c}\text { Depression } \\
(\%)\end{array}$ \\
\hline Normal & $44(40.74)$ & $38(35.19)$ & $25(23.15)$ \\
Mild & $20(18.52)$ & $4(3.70)$ & $5(4.63)$ \\
Moderate & $27(25.00)$ & $15(13.89)$ & $32(29.63)$ \\
Severe & $17(15.74)$ & $10(9.26)$ & $13(12.04)$ \\
Extremely severe & 0 & $41(37.96)$ & $33(30.56)$ \\
Total no. of students & $64(59.26)$ & $70(64.81)$ & $83(76.85)$ \\
\hline
\end{tabular}

Table 4. Proportion comparisons between stress, anxiety and depression levels of sociodemographic, class year, financial assistance and tuition funding.

\begin{tabular}{|c|c|c|c|c|c|c|c|}
\hline & & \multirow{2}{*}{$\begin{array}{c}\text { Stress } \\
\text { Median }\end{array}$} & \multicolumn{3}{|c|}{ Anxiety } & \multicolumn{2}{|c|}{ Depression } \\
\hline & & & Range & Median & Range & Median & Range \\
\hline \multirow[t]{3}{*}{ Gender } & Females & 8 & 15 & $8^{*}$ & 21 & $10^{*}$ & 21 \\
\hline & Males & 7 & 15 & 4 & 15 & 7 & 21 \\
\hline & Prefer not to say & 11 & 2 & 8.5 & 9 & 12 & 8 \\
\hline \multirow[t]{5}{*}{ Class Year } & $1^{\text {st }}$ year $(2021)$ & 8 & 14 & 7 & 19 & 10 & 19 \\
\hline & $2^{\text {nd }}$ year $(2022)$ & 10 & 15 & 7 & 18 & 9 & 20 \\
\hline & $3^{\text {rd }}$ year $(2023)$ & 8 & 14 & 7 & 21 & 8 & 20 \\
\hline & $4^{\text {th }}$ year $(2024)$ & 8 & 15 & 7 & 15 & 9 & 21 \\
\hline & $5^{\text {th }}$ year $(2025)$ & 9 & 13 & 8 & 15 & 10 & 19 \\
\hline \multirow[t]{5}{*}{ Living situation } & Dormitory & 6 & 7 & 5 & 6 & 8 & 13 \\
\hline & Live alone & 5 & 12 & 2 & 8 & 5 & 16 \\
\hline & With Family & 9 & 15 & 8 & 21 & 10 & 21 \\
\hline & With spouse/children & 9 & 5 & 7 & 14 & 6 & 3 \\
\hline & other & 8 & 4 & 14 & 13 & 13 & 12 \\
\hline \multirow[t]{2}{*}{ Financial Assistance } & No & 7 & 15 & 6.5 & 18 & 8 & 21 \\
\hline & Yes & 9 & 15 & 8 & 21 & 10 & 21 \\
\hline \multirow[t]{4}{*}{ Tuition Funding } & $\begin{array}{l}\text { Government Assistance for Tuition } \\
\text { Expenses Programme (G.A.T.E) }\end{array}$ & 8 & 15 & 7 & 17 & 8 & 21 \\
\hline & Partial/Full Scholarship & 9 & 14 & 8 & 21 & 12 & 18 \\
\hline & Self-Funded & 7 & 14 & 8 & 18 & 8 & 19 \\
\hline & Other & 8 & 12 & 8 & 17 & 8 & 18 \\
\hline
\end{tabular}

Mann-Whitney test, ${ }^{*}$ is significant at $<0.05$. Kruskal-Wallis test, ${ }^{*}$ is significant at $<0.05$.

The likelihood of having depression and anxiety was greater for students who lived alone. However, dental students who lived with family were more likely to be stressed than any other living situation. Students whose tuition was funded from the Government Assistance for Tuition Expenses Programme (G.A.T.E) 
Table 5. Logistic regression for stress, anxiety, depression with nationality, gender, class year, household, financial assistance, and tuition funding.

\begin{tabular}{|c|c|c|c|c|c|c|c|}
\hline & & \multicolumn{2}{|l|}{ Stress } & \multicolumn{2}{|l|}{ Anxiety } & \multicolumn{2}{|c|}{ Depression } \\
\hline & & $\operatorname{EXP}(\beta)$ & $95 \% \mathrm{CI}$ & $\operatorname{EXP}(\beta)$ & $95 \% \mathrm{CI}$ & $\operatorname{EXP}(\beta)$ & $95 \% \mathrm{CI}$ \\
\hline \multirow[t]{3}{*}{ Gender } & Female & -2.31 & $-5.45,0.82$ & -0.21 & $-2.86,2.44$ & -0.38 & $-3.04,2.28$ \\
\hline & Males & -3.12 & $-6.28,0.04$ & -1.22 & $-3.95,1.51$ & -1.74 & $-4.49,1$ \\
\hline & Prefer not to say & $0^{\mathrm{a}}$ & & $0^{\mathrm{a}}$ & & $0^{\mathrm{a}}$ & \\
\hline \multirow[t]{8}{*}{ Nationality } & Bahamian & -19.43 & $-19.43,-19.43$ & -0.17 & $-5.6,5.26$ & -21.34 & $-21.34,-21.34$ \\
\hline & Barbadian & -3.02 & $-7.11,1.08$ & -0.87 & $-4.56,2.81$ & -1.82 & $-5.3,1.67$ \\
\hline & British & -19.52 & $-19.52,-19.52$ & -39.94 & $-39.94,-39.94$ & -22.8 & $-22.8,-22.8$ \\
\hline & Grenadian & -21.25 & $-21.25,-21.25$ & -21.38 & $-21.38,-21.38$ & -2.01 & $-6.47,2.46$ \\
\hline & Jamaican & -2.12 & $-6.38,2.14$ & -1.13 & $-5.1,2.83$ & 0.09 & $-3.62,3.8$ \\
\hline & Nigerian & -21.43 & $-21.43,-21.43$ & -19.42 & $-19.42,-19.42$ & -2.79 & $-7.95,2.37$ \\
\hline & Trinidadian & -2.2 & $-5.12,0.72$ & -0.79 & $-3.69,2.11$ & -0.8 & $-3.36,1.75$ \\
\hline & Vincentian & $0^{\mathrm{a}}$ & & $0^{\mathrm{a}}$ & & $0^{\mathrm{a}}$ & \\
\hline \multirow[t]{5}{*}{ Year of Study } & $1^{\text {st }}$ year & 0.18 & $-2.63,3$ & 0.81 & $-0.53,2.15$ & 0.36 & $-0.94,1.67$ \\
\hline & $2^{\text {nd }}$ year & -0.06 & $-2.74,2.62$ & 0.11 & $-1.01,1.23$ & -0.07 & $-1.17,1.04$ \\
\hline & $3^{\text {rd }}$ year & -0.84 & $-3.35,1.67$ & 0.42 & $-0.86,1.7$ & -0.58 & $-1.83,0.67$ \\
\hline & $4^{\text {th }}$ year & -0.81 & $-2.92,1.3$ & 0.13 & $-1.03,1.29$ & 0.12 & $-1.02,1.26$ \\
\hline & $5^{\text {th }}$ year & $0^{\mathrm{a}}$ & & $0^{\mathrm{a}}$ & & $0^{\mathrm{a}}$ & \\
\hline \multirow[t]{5}{*}{ Living situation } & Dormitory & 0.72 & $-3.27,4.71$ & -19.84 & $-13,962.56,13,922.89$ & -0.1 & $-4.19,4$ \\
\hline & Live alone & 0.34 & $-3.15,3.83$ & -19.86 & $-13,962.58,13,922.86$ & -2.24 & $-5.77,1.29$ \\
\hline & With Family & 1.19 & $-1.97,4.34$ & -18.56 & $-13,961.28,13,924.16$ & -1.13 & $-4.33,2.08$ \\
\hline & With spouse/children & $0^{\mathrm{a}}$ & & -19.32 & $-13,962.04,13,923.4$ & -3.31 & $-7.55,0.93$ \\
\hline & other & $0^{\mathrm{a}}$ & & $0^{\mathrm{a}}$ & & $0^{\mathrm{a}}$ & \\
\hline \multirow[t]{2}{*}{ Financial Assistance } & No & -0.6 & $-1.4,0.2$ & -0.35 & $-1.13,0.44$ & -0.31 & $-0.31,-1.11$ \\
\hline & Yes & $0^{\mathrm{a}}$ & & $0^{\mathrm{a}}$ & & $0^{\mathrm{a}}$ & \\
\hline \multirow[t]{4}{*}{ Tuition Funding } & G.A.T.E & 0.001 & $-1.11,1.11$ & 0.18 & $-0.92,1.29$ & -0.56 & $-1.66,0.53$ \\
\hline & Partial/Full Scholarship & 0.22 & $-1.01,1.45$ & 0.3 & $-0.94,1.54$ & 0.28 & $-0.92,1.48$ \\
\hline & Self-Funded & -0.08 & $-1.5,1.34$ & 0.05 & $-1.36,1.46$ & -0.66 & $-2.05,0.73$ \\
\hline & Other & $0^{\mathrm{a}}$ & & $0^{\mathrm{a}}$ & & $0^{\mathrm{a}}$ & \\
\hline
\end{tabular}

${ }^{a}$ This parameter is set to zero because it is redundant.

were least likely to have depression, anxiety and stress when compared to the other means of tuition funding.

Table 6 showed the different coping strategies of the dental students. The majority of students used watching TV/movies/reading (85.2\%) to cope with stress during the COVID-19 pandemic. Whereas the least number of students used drugs/cigarettes/marijuana (3.7\%). However, $9.5 \%$ of students who selected other used music as a method to cope with stress. 
Table 6. Students' strategies for coping with stress during COVID-19 pandemic $\mathrm{N}=108$.

\begin{tabular}{ccc}
\hline Coping Method & N & $\%$ \\
\hline New hobbies & 52 & 48.2 \\
Spending time with family & 72 & 66.7 \\
Outdoor Activities & 46 & 42.6 \\
Exercise & 62 & 57.4 \\
Therapy & 9 & 8.3 \\
Spending time on social media & 78 & 72.2 \\
Watching TV/movies and reading & 92 & 85.2 \\
Consuming alcohol/cigarettes & 20 & 18.5 \\
Use of drugs & 4 & 3.7 \\
Smoking of cigarettes/marijuana & 4 & 3.7 \\
Prayer and spiritual life & 47 & 43.5 \\
Playing video games & 27 & 25.0 \\
Other & 21 & 19.4 \\
\hline
\end{tabular}

\section{Discussion}

This self-administered questionnaire demonstrated increased levels of stress (59.26\%), anxiety (64.81\%), and depression (76.85\%) among dental students during this pandemic. This was higher than reported in other studies (Chakraborty et al., 2020; Hakami et al., 2021; Škrlec, Talapko, Pustijanac, \& Meštrović, 2021). These increased levels support the role of the ongoing pandemic on the mental health of persons in the dental fraternity (Ahmed et al., 2020). Compared to past pandemics, COVID-19 is associated with higher levels of anxiety. For example during the MERS-CoV outbreak in 2014 only mild to moderate anxiety was reported in students (Al-Rabiaah et al., 2020). Conversely in this study $64.81 \%$ of respondents reported severe and extremely severe levels of anxiety.

The levels of depression in this study were also much higher than other studies (Chakraborty et al., 2020). At the time the survey was conducted, Trinidad was going through its second deadly wave of COVID-19 outbreak and had been struggling with this pandemic for 11 months.

Indeed female students were more likely to report feelings of stress, anxiety and depression than males. This was similar to findings in other studies (Škrlec et al., 2021). These results may be due to cultural, social and biological factors that affect female mental health (Blane, 1995).

In addition, depression and anxiety were more likely reported in students who lived alone. This was concurrent with other studies (Harrison, Barrow, Gask, \& Creed, 1999; Joutsenniemi, Martelin, Martikainen, Pirkola, \& Koskinen, 2006). This was probably due to enforced locked downs and social distancing laws which resulted in students feeling isolated, lonely and detached.

Interestingly, higher stress was found in students who lived with family com- 
pared to all other living situations. This was similar to findings in a sample of dental students in Turkey (Yildirm \& Atas, 2021) and is possibly related to dental students fear of infecting family members with the COVID-19 virus. The GATE program allows students to complete their dental programme with free tuition. The students on the GATE programme were least likely to be stressed, anxious and depressed. This is in agreement with previous studies which have shown students with financial debts have higher stress levels (Boyles \& Ahmed, 2017).

In this study, there was no association between year of study and levels of stress, anxiety and depression. This was similar to findings of Özdede and Sahin (2020). But these finding didn't mirror other studies that associated year of study with levels of stress (Hakami et al., 2021; Loh, Ali, Ang, \& Chelliah, 2006). They found that students in clinical years had more mental health concerns than preclinical years.

Stress management among dental students usually entailed one technique or a combination of techniques (Alzahem et al., 2014). Students reported common coping strategies like watching television, reading, spending time on social media and spending time with family were the most common strategies for coping. This was similar to other study findings (Kobbin, Jzui, Teo, Hui, \& Halim, 2020) and shows the protective strategies used against the psychological impact of this pandemic.

\section{Conclusion}

The response rate for this study was very high. This highlights the students' desire during this pandemic to share their thoughts. Despite this, there are disadvantages associated with self-reported data such as reporting bias and introspective ability. Also, this cross-sectional study was conducted during the second wave of the pandemic and the students' dental curriculum had been interrupted for 11 months. There was therefore no baseline data for this group of students and nothing to compare to ascertain if the situation is declining or improving. More studies are recommended at different phases of the pandemic. Nevertheless this study provides insight into the impact of the pandemic on dental students in the Caribbean.

Higher levels of stress, anxiety and depression were seen among dental students in Trinidad and Tobago during the COVID-19 pandemic. This study found female students were more likely to experience stress, anxiety and depression compared to males and that there were several strategies deployed by students to cope. This study recommends that there is a high need for psychological intervention.

\section{Conflicts of Interest}

The authors declare no conflicts of interest regarding the publication of this paper. 


\section{References}

Adams, D. F. (2017). The Embedded Counseling Model: An Application to Dental Students. Journal of Dental Education, 81, 29-35. https://doi.org/10.1002/j.0022-0337.2017.81.1.tb06244.x

Ahmad, M. S., Md Yusoff, M. M., \& Abdul Razak, I. (2011). Stress and Its Relief among Undergraduate Dental Students in Malaysia. Southeast Asian Journal of Tropical Medicine and Public Health, 42, 996-1004.

Ahmed, M. A., Jouhar, R., Ahmed, N., Adnan, S., Aftab, M., Zafar, M. S., \& Khurshid, Z. (2020). Fear and Practice Modifications among Dentists to Combat Novel Coronavirus Disease (COVID-19) Outbreak. International Journal of Environmental Research and Public Health, 17, Article No. 2821. https://doi.org/10.3390/ijerph17082821

Al-Rabiaah, A., Temsah, M. H., Al-Eyadhy, A. A., Hasan, G. M., Al-Zamil, F., Al-Subaie, S. et al. (2020). Middle East Respiratory Syndrome-Corona Virus (MERS-CoV) Associated Stress among Medical Students at a University Teaching Hospital in Saudi Arabia. Journal of Infection and Public Health, 13, 687-691. https://doi.org/10.1016/j.jiph.2020.01.005

Al-Sowygh, Z. H., Alfadley, A. A., Al-Saif, M. I., \& Al-Wadei, S. H. (2013). Perceived Causes of Stress among Saudi Dental Students. King Saud University Journal of Dental Sciences, 4, 7-15. https://doi.org/10.1016/j.ksujds.2012.11.002

Alzahem, A. M., Van der Molen, H. T., Alaujan, A. H., \& De Boer, B. J. (2014). Stress Management in Dental Students: A Systematic Review. Advances in Medical Education and Practice, 5, 167-176. https://doi.org/10.2147/AMEP.S46211

Bashir, T. F., Hassan, S., Maqsood, A., Khan, Z. A., Issrani, R., Ahmed, N., \& Bashir, E. F. (2020). The Psychological Impact Analysis of Novel COVID-19 Pandemic in Health Sciences Students: A Global Survey. European Journal of Dentistry, 14, S91-S96. https://doi.org/10.1055/s-0040-1721653

Basudan, S., Binanzan, N., \& Alhassan, A. (2017). Depression, Anxiety and Stress in Dental Students. International Journal of Medical Education, 8, 179-186.

https://doi.org/10.5116/ijme.5910.b961

Blane, D. (1995). Social Determinants of Health-Socioeconomic Status, Social Class, and Ethnicity. American Journal of Public Health, 85, 903-905. https://doi.org/10.2105/AJPH.85.7.903

Boyles, J. D., \& Ahmed, B. (2017). Does Student Debt Affect Dental Students' and Dentists' Stress Levels? British Dental Journal, 223, 601-606. https://doi.org/10.1038/sj.bdj.2017.876

Burk, D. T., \& Bender, D. J. (2005). Use and Perceived Effectiveness of Student Support Services in a First-Year Dental Student Population. Journal of Dental Education, 69, 1148-1160. https://doi.org/10.1002/j.0022-0337.2005.69.10.tb04016.x

Cao, W., Fang, Z., Hou, G., Han, M., Xu, X., Dong, J., \& Zheng, J. (2020). The Psychological Impact of the COVID-19 Epidemic on College Students in China. Psychiatry Research, 287, Article ID: 112934. https://doi.org/10.1016/j.psychres.2020.112934

Chakraborty, T., Subbiah, G. K., \& Damade, Y. (2020). Psychological Distress during COVID-19 Lockdown among Dental Students and Practitioners in India: A CrossSectional Survey. European Journal of Dentistry, 14, S70-S78. https://doi.org/10.1055/s-0040-1719211

Charan, R. (2020, March 12). T\&T Confirms First Case of Coronavirus, Breaking Top Story. Trinidad Express.

https://trinidadexpress.com/newsextra/t-t-confirms-first-case-of-coronavirus/article_5 
c05b35a-6495-11ea-8bd4-1bba999d27a3.html

CODA (Commission on Dental Association) (2016). Accreditation Standards for Dental Education Programs. Commission on Dental Association. http://www.ada.org/coda

Cooper, C. L., Watts, J., \& Kelly, M. (1987). Job Satisfaction, Mental Health, and Job Stressors among General Dental Practitioners in the UK. British Dental Journal, 162, 77-81. https://doi.org/10.1038/sj.bdj.4806030

Divaris, K., Barlow, P. J., Chendea, S. A., Cheong, W. S., Dounis, A., Dragan, I. F. et al. (2008). The Academic Environment: The Students' Perspective. European Journal of Dental Education, 12, 120-130. https://doi.org/10.1111/j.1600-0579.2007.00494.x

Fangyuan, T., Li, H., Tian, S., Yang, J., Shao, J., \& Tian, C. (2020). Psychological Symptoms of Ordinary Chinese Citizens Based on SCL-90 during the Level I Emergency Response to COVID-19. Psychiatry Research, 288, Article ID: 112992. https://doi.org/10.1016/j.psychres.2020.112992

Ge, Z. Y., Yang, L. M., Xia, J. J., Fu, X. H., \& Zhang, Y. Z. (2020). Possible Aerosol Transmission of COVID-19 and Special Precautions in Dentistry. Journal of Zhejiang University-SCIENCE B, 21, 361-368. https://doi.org/10.1631/jzus.B2010010

Hakami, Z., Khanagar, S. B., Vishwanathaiah, S., Hakami, A., Bokhari, A. M., Jabali, A. H. et al. (2021). Psychological Impact of the Coronavirus Disease 2019 (COVID-19) Pandemic on Dental Students: A Nationwide Study. Journal of Dental Education, 85, 494-503. https://doi.org/10.1002/jdd.12470

Harrison, J., Barrow, S., Gask, L., \& Creed, F. (1999). Social Determinants of GHQ Score by Postal Survey. Journal of Public Health, 21, 283-288.

https://doi.org/10.1093/pubmed/21.3.283

Henry, J. D., \& Crawford, J. R. (2005). The Short-Form Version of the Depression Anxiety Stress Scales (DASS-21): Construct Validity and Normative Data in a Large Non-Clinical Sample. British Journal of Clinical Psychology, 44, 227-239.

Holland, D. (2016). College Student Stress and Mental Health: Examination of Stigmatic Views on Mental Health Counseling. Michigan Sociological Review, 30, 16-43.

Holmes, E. A., O’Connor, R. C., Perry, V. H., Tracey, I., Wessely, S., Arseneault, L. et al. (2020). Multidisciplinary Research Priorities for the COVID-19 Pandemic: A Call for Action for Mental Health Science. Lancet Psychiatry, 7, 547-560. https://doi.org/10.1016/S2215-0366(20)30168-1

Hoyte, T., Henry, K., Kowlessar, A., Ali, A., \& Mahabir, A. (2021). Factors Affecting the Career and Speciality Preferences of Dental Students in Trinidad and Tobago: A Cross-Sectional Survey. Creative Education, 12, No. 8, 1792-1804. https://doi.org/10.4236/ce.2021.128136

Iyer, P., Aziz, K., \& Ojcius, D. M. (2020). Impact of COVID-19 on Dental Education in the United States. Journal of Dental Education, 84, 718-722. https://doi.org/10.1002/jdd.12163

Joutsenniemi, K., Martelin, T., Martikainen, P., Pirkola, S., \& Koskinen, S. (2006). Living Arrangements and Mental Health in Finland. Journal of Epidemiology \& Community Health, 60, 468-475. https://doi.org/10.1136/jech.2005.040741

Kelly, H. (2011). The Classical Definition of a Pandemic Is Not Elusive. Bulletin of the World Health Organization, 89, 539-540. https://doi.org/10.2471/BLT.11.088815

Klaassen, H., Ashida, S., Comnick, C. L., Xie, X. J., Smith, B. M., Tabrizi, M. et al. (2021). COVID-19 Pandemic and Its Impact on Dental Students: A Multi-Institutional Survey. Journal of Dental Education, 85, 1280-1286. https://doi.org/10.1002/jdd.12597

Kobbin, V., Jzui, N. W., Teo, M., Hui, T. X., \& Halim, I. (2020). Fear, Anxiety and Coping 
Mechanism during COVID-19 Pandemic among Undergraduates. Intern. International Journal of Biomedical and Clinical Engineering, 5, 217-228.

Laurence, B., Williams, C., \& Eiland, D. (2009). Depressive Symptoms, Stress, and Social Support among Dental Students at a Historically Black College and University. Journal of American College Health, 58, 56-63. https://doi.org/10.3200/JACH.58.1.56-63

Loh, L.-C., Ali, A. M., Ang, T.-H., \& Chelliah, A. (2006). Impact of a spreading epidemic on Medical Students. The Malaysian Journal of Medical Sciences, 13, 30-36.

https://pubmed.ncbi.nlm.nih.gov/22589602 https://www.ncbi.nlm.nih.gov/pmc/articles/PMC3349482/

Lovibond, S. H., Lovibond, P. F., \& Psychology Foundation of Australia (1995). Manual for the Depression Anxiety Stress Scales. Psychology Foundation of Australia.

Meng, L., Hua, F., \& Bian, Z. (2020). Coronavirus Disease 2019 (COVID-19): Emerging and Future Challenges for Dental and Oral Medicine. Journal of Dental Research, 99, 481-487. https://doi.org/10.1177\%2F0022034520914246

Özdede, M., \& Sahin, S. (2020). Views and Anxiety Levels of Turkish Dental Students during the COVID-19 Pandemic. Journal of Stomatology, 73, 123-128.

https://doi.org/10.5114/jos.2020.96867

Phelan, A. L., Katz, R., \& Gostin, L. O. (2020). The Novel Coronavirus Originating in Wuhan, China: Challenges for Global Health Governance. JAMA, 323, 709-710. https://doi.org/10.1001/jama.2020.1097

Polychronopoulou, A., \& Divaris, K. (2005). Perceived Sources of Stress among Greek Dental Students. Journal of Dental Education, 69, 687-692.

https://doi.org/10.1002/j.0022-0337.2005.69.6.tb03952.x

Škrlec, I., Talapko, J., Pustijanac, E., \& Meštrović, T. (2021). Depression, Anxiety, Stress and Physical Activity in Health-Related University Students during COVID-19. The 3rd International Electronic Conference on Environmental Research and Public Health, $1-6$.

Sreeram, M., \& Mundada, M. A. (2021). Survey to Assess Perceived Causes of Stress, Its Manifestations and Coping Strategies among Dental College Students in Maharashtra during COVID-19 Lockdown. Biomedical \& Pharmacology Journal, 14, 53-60. https://doi.org/10.13005/bpj/2098

Wang, X., Hegde, S., Son, C., Keller, B., Smith, A., \& Sasangohar, F. (2020). Investigating Mental Health of US College Students during the COVID-19 Pandemic: Cross-Sectional Survey Study. Journal of Medical Internet Research, 22, e22817.

https://doi.org/10.2196/22817

World Health Organization (2020). WHO Timeline-COVID-19. https://www.who.int/emergencies/diseases/novel-coronavirus-2019/interactive-timeline

Yildirm, T. T., \& Atas, O. (2021). The Evaluation of Psychological State of Dental Students during the COVID-19 Pandemic. Brazilian Oral Research, 35, Article No. 0069. https://doi.org/10.1590/1807-3107bor-2021.vol35.0069 http://www.scielo.br/scielo.php?script=sci_arttext\&pid=S1806-83242021000100245\&nr $\underline{\mathrm{m}=\mathrm{iso}}$

Zhai, Y., \& Du, X. (2020). Mental Health Care for International Chinese Students Affected by the COVID-19 Outbreak. The Lancet Psychiatry, 7, e22. https://doi.org/10.1016/S2215-0366(20)30089-4 